\title{
Fenugreek Trigonella foenum-graceum L. as a feeding deterent to the pea aphid Acyrthosiphon pisum Harris.
}

\section{Ocena kozieradki pospolitej Trigonella foenum-graceum L. jako deterenta pokarmowego mszycy grochowej Acyrthosiphon pisum Harris.}

\author{
Bożena Kordan, Paweł Słomiński, Mariusz Nietupski, Krystyna Żuk-Gołaszewska
}

\section{Summary}

The aim of the study was to evaluate the effect of the fenugreek Trigonella foenum-graceum L. on the feeding of the pea aphid Acyrthosiphon pisum Harris on peas Pisum sativum L. The parameters derived from 8-hour EPG (Electrical Penetration Graph) recordings were analysed. The following combinations were studied: peas covered with the extract from the fine ground seeds of the fenugreek, peas watered with the extract from fenugreek seeds, peas grown together with fenugreek, and peas grown in the soil with the addition of the fenugreek ground seeds. The results have shown that the fenugreek did not reduce the feeding of the pea aphid on peas. The phloem sap ingestion predominated in aphid activities in almost all combinations. The penetration of extra-phloem tissues prevailed only on plants grown together with the fenugreek. The longest time spent on phloem sap ingestion by $A$. pisum was found on control plants and plants watered or covered with the fenugreek seed extract.

Key words: aphidoidea, Acyrthosiphon pisum Harris., Pisum sativum L., Trigonella foenum-graceum L., EPG (Electrical Penetration Graph)

\section{Streszczenie}

Celem badań była ocena wpływu kozieradki pospolitej Trigonella foenum-graceum L. na żerowanie mszycy grochowej Acyrthosiphon pisum Harris na grochu pospolitym Pisum sativum L. Analizowano parametry uzyskane podczas 8-godzinnych rejestracji EPG (Electrical Penetration Graph). W badaniach zastosowano kombinacje: rośliny grochu pokryte wyciągiem z drobno zmielonych nasion kozieradki pospolitej, rośliny grochu podlane wyciągiem z nasion kozieradki pospolitej, rośliny grochu wyhodowane z nasion wspólnie wysianych z nasionami kozieradki, rośliny grochu wyhodowane z nasion, które wysiano do gleby z dodatkiem zmielonych nasion kozieradki. Uzyskane wyniki wykazały, że kozieradka pospolita nie ogranicza żerowania mszycy grochowej na grochu siewnym. W aktywności $A$. pisum prawie we wszystkich badanych kombinacjach dominowała faza floemowa. Tylko na roślinach grochu, których nasiona wysiano wspólnie z nasionami kozieradki, mszyce więcej czasu spędzały na penetracji tkanek pozafloemowych.

Słowa kluczowe: aphidoidea, Acyrthosiphon pisum Harris., Pisum sativum L., Trigonella foenum-graceum L., EPG (Electrical Penetration Graph)

\footnotetext{
Uniwersytet Warmińsko-Mazurski w Olsztynie

Katedra Fitopatologii i Entomologii

Prawocheńskiego 17, 10-720 Olsztyn

bozena.kordan@uwm.edu.pl
} 


\section{Wstęp / Introduction}

Mszyca grochowa (Acyrthosiphon pisum Harris.) jest jednym z najważniejszych szkodników roślin bobowatych (Fabaceae). Szczególnie duże znaczenie gospodarcze ma w uprawach grochu, bobiku, lucerny, soczewicy i koniczyny (Wójtowska 1990; Sądej 1993; Sandstrom 1994; Olbrycht 1999; Sądej i Nietupski 2000; Olbrycht i Wiech 2003; Zhu i wsp. 2005). Najchętniej żeruje na wierzchołkach pędu, pąkach kwiatostanowych i najmłodszych liściach. Szkodliwość mszyc polega na wkłuwaniu się i penetrowaniu tkanek roślinnych, mechanicznym ich uszkadzaniu, pobieraniu podstawowych metabolitów roślinnych co wpływa na obniżenie natężenia procesu fotosyntezy w zaatakowanych komórkach. Wprowadzona przy tym do tkanek ślina zmienia metabolizm rośliny. Następują zaburzenia w przewodzeniu asymilatów i wody w roślinie. Uszkodzone rośliny nie rosną, częściowo ulegają zniekształceniu, więdną, żółkną i usychają. Najsilniej uszkadzane są wierzchołki roślin, na których mszyce tworzą najczęściej kolonie. Pośrednia szkodliwość mszyc polega między innymi na przenoszeniu wirusów. Główną rolę w kształtowaniu wyboru rośliny żywicielskiej odgrywa chemia roślin (Caillaud i Via 2000). Każdy wyspecjalizowany gatunek mszyc rozpoznaje związki chemiczne właściwe dla preferowanej przez siebie rośliny, co wywołuje przystapienie do żerowania. W przypadku mszyc grochowych badania wykazały, że skład związków odżywczych w roślinach nie wystarczy do wyjaśnienia specjalizacji owadów względem rośliny żywiciela (Del Campo i wsp. 2003). Bardzo silny wpływ na wykorzystanie roślin żywicieli przez mszycę grochową mają allelozwiązki (Dreyer i wsp. 1985; Berlandier 1996). W środowisku naturalnym poszukuje się roślin, zawierających związki chemiczne, które mogłyby wpływać na zaburzenie rozpoznawania roślin żywicielskich przez mszycę, a tym samym ograniczać ich żerowanie.

Kozieradka pospolita (Trigonella foenum-graceum L.) należy do roślin leczniczych, których znaczenie w ostatnim okresie wzrasta. Częścią użytkową są głównie nasiona, jak i w mniejszym stopniu masa wegetatywna. Nasiona są doskonałym komponentem pasz, mają bogaty skład i charakterystyczny, dość intensywny zapach. Zawierają one 26,03-29,5\% białka o dużej wartości biologicznej, a także tłuszcz, dużo śluzu i ślady olejku eterycznego, saponin (diosgenina, tiggenina, yamogenin, gitogenina), flawonoidy (witeksyna, wicenina, izowiteksyna, luteolina, orientyna, kwercetyna), cholinę oraz witaminy PP i trygonolinę. Zawartość lipidów w nasionach kozieradki waha się od 7 do $10 \%$ suchej masy. W ich skład wchodzą głównie tłuszcze neutralne, tj. związki z grupy diglicerydów $(6,3 \%)$ i triglicerydów $(86,1 \%)$, glikolipidy $(5,4 \%)$ oraz fosfolipidy (10,5\%). Zawierają również niewielkie ilości monoglicerydów, wolnych kwasów tłuszczowych i steroli (Hemavathy i Prabhakar 1988).

Celem podjętych badań była ocena kozieradki pospolitej jako deterenta pokarmowego mszycy grochowej.

\section{Materiały i metody / Materials and methods}

Mszyce i rośliny pochodziły z hodowli prowadzonej w komorze fitotronowej Sanyo MLR 350 (temperatura $\left.20^{\circ} \mathrm{C}, 14: 10 \mathrm{~L}: \mathrm{D}, 60 \% \mathrm{RH}\right)$. Do badań wykorzystano groch siewny (Pisum sativum L.) odmiany Bohun (faza 3-4 liści) oraz dorosłe, bezskrzydłe osobniki mszycy grochowej A. pisum Harris. Wpływ T. foenum-graecum L. na zachowanie $A$. pisum testowano w następujących kombinacjach:

I. Rośliny grochu pokryte wyciagiem $\mathrm{z}$ drobno zmielonych nasion $T$. foenum-graecum (100 g zmielonych nasion $+500 \mathrm{ml}$ wody destylowanej - odsączano po $24 \mathrm{~h}$ ).

II. Rośliny grochu, które podlewano wyciagiem $\mathrm{z}$ drobno zmielonych nasion $T$. foenum-graecum (co $12 \mathrm{~h}$ na trzy doby przed badaniem - uzyskany wyciąg rozcieńczano wodą destylowaną w stosunku 1:10).

III. Rośliny grochu, które wyhodowano $\mathrm{z}$ nasion wysianych wspólnie z nasionami $T$. foenum-graecum.

IV.Rośliny grochu, które wyhodowano $\mathrm{z}$ nasion wysianych do ziemi z 10\% domieszką zmielonych nasion T. foenum-graecum

Kontrolę stanowiły rośliny w czystym siewie.

Ocenę zachowania mszycy grochowej na badanych roślinach przeprowadzono w warunkach laboratoryjnych przy pomocy techniki elektronicznej rejestracji zachowania się mszyc (EPG - Electrical Penetration Graph) (Gabryś 2000). Metoda ta umożliwia określenie lokalizacji sztyletów mszyc w tkankach roślinnych w trakcie żerowania, a analizy rejestracji EPG są między innymi źródłem informacji o obecności związków roślinnych o właściwościach deterentnych. Dla każdej kombinacji przeprowadzono w 12 powtórzeniach 8-godzinne rejestracje. W analizie rejestracji wyszczególniono etapy braku penetracji tkanek roślinnych oraz okresy, w których kłujka mszyc penetruje tkanki roślinne. Ponadto określono średni czas trwania takich parametrów, jak: faza ścieżki (C) odpowiadająca penetracji tkanek pozafloemowych epidermy i miękiszu, faza ksylemowa (G) obrazująca pobieranie wody z ksylemu, model F odpowiadający prawdopodobnie trudnościom $\mathrm{w}$ penetracji wywołanym czynnikami mechanicznochemicznymi, faza floemowa (E) obejmująca wydzielanie śliny i pobieranie soku floemowego (Gabryś 2000). W celu porównania wartości uzyskanych parametrów EPG przeprowadzono analizę statystyczną, w której wykorzystano test nieparametryczny U Manna-Whitneya (STATISTICA 11).

\section{Wyniki i dyskusja / Results and discussion}

Podczas rejestracji żerowania $A$. pisum na wszystkich badanych roślinach wystapiły modele faz obrazujące penetracje tkanek epidermy i miękiszu, wydzielanie śliny i pobieranie soku floemowego, trudności mechanicznochemiczne w penetracji tkanek oraz pobieranie wody z ksylemu (tab. 1). Mszyca grochowa na wszystkich roślinach większość czasu spędzała na czynnościach związanych $\mathrm{z}$ penetracją tkanek roślinnych. Średni czas braku penetracji był najdłuższy w próbach, gdzie rośliny grochu pokryto wyciagiem $\mathrm{z}$ drobno zmielonych nasion kozieradki pospolitej. Można przypuszczać, że wyciągi te zaburzają proces wyboru rośliny żywicielskiej przez A. pisum. Analizując jednak średnie czasy aktywności mszycy grochowej stwierdzono, że A. pisum zdecydowanie więcej czasu spędzała na penetracji tkanek roślinnych. Bardzo krótki czas braku penetracji tkanek roślinnych 
Tabela 1. Wartości parametrów uzyskanych w trakcie 8-godzinnej rejestracji zachowania się mszycy grochowej $A$. pisum na grochu siewnym $P$. sativum

Table 1. Values of the parameters obtained basing on 8-hour probing behaviour of the pea aphid A.pisum on the peas P. sativum

\begin{tabular}{l|c|c|c|c|c}
\hline \multirow{2}{*}{\multicolumn{1}{c}{ Parametry - Parameters }} & \multicolumn{5}{c}{ Groch siewny (Pisum sativum L.) - Peas } \\
\cline { 2 - 6 } & \multicolumn{4}{|c|}{ kombinacje - combination } \\
\cline { 2 - 6 } & I & II & III & IV & Kontrola - Control \\
\hline $\begin{array}{l}\text { Średni czas ścieżki C (s) } \\
\text { Mean time of path C (s) }\end{array}$ & $1160,3( \pm 354)^{*}$ & $734( \pm 353)^{*}$ & $662,3( \pm 142,8) *$ & $544,7( \pm 71,7)^{*}$ & $568,8( \pm 90)^{*}$ \\
\hline $\begin{array}{l}\text { Średni czas fazy floemowej E (s) } \\
\text { Mean time of phloem phase E (s) }\end{array}$ & $6582,5( \pm 2086,6)$ & $7055,4( \pm 2061,1)$ & $2417,9( \pm 909,5)$ & $3292( \pm 688,2)$ & $4551,1( \pm 1546,4)$ \\
\hline $\begin{array}{l}\text { Średni czas fazy ksylemowej G (s) } \\
\text { Mean time of xylem phase G (S) }\end{array}$ & $383,8( \pm 264,7)$ & $320,8( \pm 179,4)$ & $0,5( \pm 0,5)$ & $664,4( \pm 534,5)$ & $361,6( \pm 259,5)$ \\
\hline $\begin{array}{l}\text { Średni czas fazy F (s) } \\
\text { Mean time F phase (s) }\end{array}$ & $549,1( \pm 364,7)$ & $829,8( \pm 508,8)$ & $3117,4( \pm 899,9)$ & $860,8( \pm 382)$ & $1307,3( \pm 648,5)$ \\
\hline $\begin{array}{l}\text { Średni czas braku penetracji Np (s) } \\
\text { Mean time of no penetration Np (s) }\end{array}$ & $453,8( \pm 157,5)$ & $95,7( \pm 14)$ & $121,7( \pm 20,3)$ & $224( \pm 84,5)$ & $176,2( \pm 26,6)$ \\
\hline
\end{tabular}

*test U Manna-Whitneya - istotne różnice między kombinacjami; $\mathrm{p}<0,05$

*U Mann-Whitney test - significant differences between combinations; $\mathrm{p}<0.05$

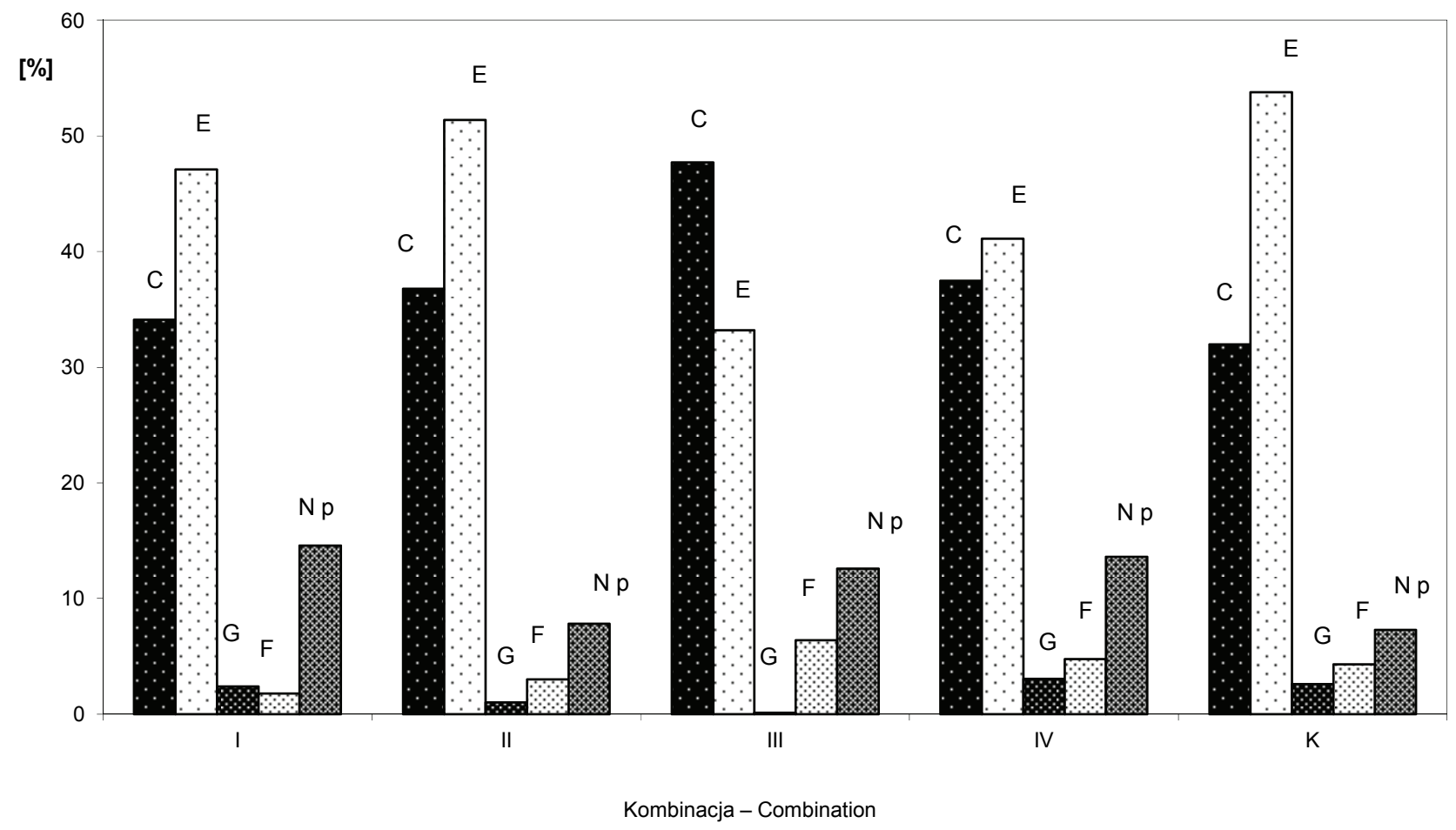

Rys. 1. Zachowanie się A. pisum podczas 8-godzinnej rejestracji żerowania na grochu siewnym $P$. sativum

I - rośliny grochu pokryte wyciagiem z drobno zmielonych nasion kozieradki, II - rośliny grochu, które podlewano wyciagiem z drobno zmielonych nasion kozieradki, III - rośliny grochu, które wyhodowano z nasion wysianych wspólnie z nasionami kozieradki, IV - rośliny grochu, które wyhodowano $\mathrm{z}$ nasion wysianych do ziemi z $10 \%$ domieszką zmielonych nasion kozieradki, $\mathrm{K}$ - kontrola, C - faza ścieżki, E - faza floemowa, G - faza ksylemowa, F - faza F, Np - brak penetracji

Fig. 1. A. pisum behaviour during a 8 -hour recording of foraging on the peas $P$. sativum

I - peas covered with the extract from the fine ground seeds of the fenugreek, II - peas watered with the extract from fenugreek seeds, III - peas grown together with fenugreek, IV - peas grown in the soil with the addition of the fenugreek ground seeds, $\mathrm{K}$ - control, $\mathrm{C}$ - pathway phasa, $\mathrm{E}$ - phloem phase, $\mathrm{G}$ - xylem phase, $\mathrm{F}$ - F phase, $\mathrm{Np}$ - no penetration

przez mszycę grochową na wszystkich badanych roślinach może świadczyć o obecności czynników stymulujących żerowanie i prawdopodobnie o braku deterentów pokarmowych. Podczas 8-godzinnej rejestracji zachowania się $A$. pisum prawie we wszystkich badanych kombinacjach dominowała faza floemowa, odpowiadająca aktywności związanej z pobieraniem soku floemowego (rys. 1). Tylko na roślinach grochu, których nasiona wysiano wspólnie z nasionami kozieradki, mszyce więcej czasu spędzały na penetracji tkanek pozafloemowych. A. pisum najchętniej 
żerowała na roślinach kontrolnych oraz na roślinach grochu siewnego, które pokryto oraz podlewano wyciągiem $\mathrm{z}$ drobno zmielonych nasion kozieradki pospolitej. $\mathrm{Na}$ tych roślinach mszyce wykorzystywały odpowiednio 53,$8 ; 47,1$ oraz $51,4 \%$ czasu penetracji na właściwe żerowanie, związane $\mathrm{z}$ pobieraniem soku floemowego (faza E). Różnic istotnych statystycznie pomiędzy wszystkimi kombinacjami nie stwierdzono (faza E). Według Montllor i Tjallingii (1989) długie fazy pobierania soku floemowego podczas penetracji tkanek roślinnych można postrzegać jako związki behawioralne określające akceptację rośliny przez mszycę.

\section{Wnioski / Conclusions}

1. Kozieradka pospolita nie ogranicza żerowania $A$. pisum na grochu siewnym $P$. sativum.

2. Długie czasy aktywności związane z pobieraniem soku floemowego przez $A$. pisum świadczą o braku właściwości deterentnych kozieradki pospolitej w stosunku do A. pisum.

3. Kozieradka pospolita może jednak zaburzać procesy wstępnej akceptacji rośliny żywicielskiej, o czym świadczą długie okresu braku penetracji tkanek roślinnych przez $A$. pisum.

\section{Literatura / References}

Berlandier F. 1996. Alkaloid level in narrow-leafed lupin, Lupinus angustifolius, influences green peach aphid reproductive performance. Entomol. Exp. Appl. 79: 19-24.

Caillaud C.M., Via S. 2000. Specialised feeding behaviour influences both ecological specialisation and assortative mating in sympatric host races of pea aphids. American Naturalist 156: 606-621.

Del Campo M.L., Via S., Caillaud M.C. 2003. Recognition of host-specific chemical stimulants in two sympatric host races of the pea aphid Acyrthosiphon pisum. Ecol. Entomol. 28: 405-412.

Dreyer D.L., Jones K.C., Molyneux R.J. 1985. Feeding deterrency of some pyrrolizidine, indolizidine and quinolizidine alkaloids towards pea aphid Acyrthosiphon pisum and evidence for phloem transport of indolizidine alkaloid swainsonine. J. Chem. Ecol. 11: $1045-1051$

Gabryś B. 2000. Powiązania między owadami i roślinami - badania nad mechanizmami odporności roślin na żerowaniem mszyc. Biotechnologia 3 (50): 69-80.

Hemavathy J., Prabhakar J.V. 1988. Lipid composition of fenugreek (Trigonella foenum-graceum L.) seeds. Food Chemistry 31: 1-7.

Montllor C., Tjallingii W.F. 1989. Stylet penetration by two aphid species on sceptible and resistant lettuce . Entomol. Exp. Appl. 52: $103-111$.

Olbrycht T. 1999. Występowanie mszycy grochowej (Acyrthosiphon pisum Harris) i związanych z nią parazytoidów na soczewicy (Lens esculata Much.) w okolicach Rzeszowa. Prog. Plant Prot./Post. Ochr. Roślin 39 (2): 416-418.

Olbrycht T., Wiech K. 2003. The effect intercropping legumes with cereals on the abundance of pea aphid (Acyrthosiphon pisum Harris). Aphids and Other Hemopterous Insects 9: 113-120.

Sandstrom J. 1994. Performance of pea aphid (Acyrthosiphon pisum) clones on host plants and synthetic diets mimicking the same plants phloem amino acid composition. J. Ins. Physiol. 40 (12): 1051-1057.

Sądej W. 1993. Mszyce (Aphididae) występujące na koniczynie czerwonej i wpływ przykaszania na ich liczebność. Pol. Pismo Entomol. 62: 139-144.

Sądej W., Nietupski M. 2000. Occurrence of pea aphid (Acyrthosiphon pisum Harris.) on faba bean and the chosen biotic factors reducing its numbers. Natur. Sci. 5: 73-82.

Wójtowska M. 1990. Wpływ różnych czynników na liczebność mszycy grochowianki na różnych roślinach motylkowatych. Zesz. Probl. Post. Nauk Rol. 392: 162-169.

Zhu J., Obrycki J.J., Ochieng S.A., Baker T.C., Pickett J.A., Smiley D. 2005. Attraction of two lacewing species to volatiles produced by host plants and aphid prey. Naturwissenschaften 92 (6): 277-281. 